\title{
EDITORIAL
}

\section{EBV and human cancer}

\author{
Experimental \& Molecular Medicine (2015) 47, e130; doi:10.1038/emm.2014.109; published online 23 January 2015
}

$\mathrm{E}^{\mathrm{p}}$ pstein-Barr virus (EBV) was the first virus shown to cause cancer in humans and is associated with a wide range of human cancers originating from epithelial cells, lymphocytes and mesenchymal cells. EBV-associated neoplasms affect both immune-competent hosts and immune-compromized patients who have received an organ transplant or who exhibit iatrogenic immune suppression. The development of an EBV-associated neoplasm is largely dependent on environmental factors and genetic susceptibility to viral infection that is associated with genetically prone immune deregulation. ${ }^{1}$

EBV leads to the extensive methylation of both the host and viral genome, and these changes facilitate cellular functions that promote viral persistence and propagation. ${ }^{2}$ EBV-positive neoplasms exhibit genetic alterations that are distinct from those exhibited by EBV-negative neoplasms. For example, EBV-positive gastric adenocarcinoma displays recurrent PIK3CA mutations, extreme DNA hypermethylation, and amplification of JAK2, CD274 and PDCD1LG2. ${ }^{3}$ Meanwhile, endemic Burkitt lymphoma is associated with lower frequencies of ID3 and TCF3 mutations compared with sporadic Burkitt lymphoma and shows strong evidence of chronic antigenic stimulation. ${ }^{4,5}$

Last year was the 50th anniversary of the discovery by Michael Anthony Epstein and Yvonne Barr of EBV particles in cell lines cultured from tumor tissue from a Burkitt lymphoma. ${ }^{6}$ As the initial discovery of the virus, $>20000$ scientific papers on the characteristics, functions and oncogenic mechanisms of viral genes, the spectrum of EBV-associated diseases and the treatment of patients have been published. To provide an overview of our current understanding of EpsteinBarr virology and oncogenesis and of EBV-associated neoplasm, for this special feature on EBV and Human Cancer, authors were invited to submit six review articles, entitled 'Epstein-Barr virus latent genes,' 'EBV-driven B-cell lymphoproliferative disorders,' 'Epstein-Barr virus-positive T/NK cell lymphoproliferative disorders,' 'Genomic assays for Epstein-Barr virus-positive gastric adenocarcinoma,' 'Modeling EBV infection and pathogenesis in new-generation humanized mice' and 'Epstein Barr virus-associated lymphoproliferative diseases: the virus as a therapeutic target.'
Understanding the role of EBV latent genes is essential for identifying the mechanism underlying EBV-induced cell transformation and immune evasion, although lytic EBV reactivation also contributes to the development of EBV-associated neoplasm. ${ }^{7}$ Myong-Soo Kang is a molecular biologist and virologist at Sungkyunkwan University School of Medicine, Seoul, Korea, whose previous work on EBV latent genes identified the mechanism of EBV LMP1-induced NF- $\mathrm{B}$ activation. ${ }^{8}$ This review discusses the roles of latent EBV genes and the miRNAs whose functions are known.

EBV is associated with a subset of Hodgkin's lymphoma, a subset of diffuse large B-cell lymphoma (DLBCL), and endemic Burkitt lymphoma. In addition to EBV-associated malignant B-cell lymphoma, age-related EBV-positive B-lymphoproliferative diseases (LPDs), which pathologically span from reactive hyperplasia to monomorphous lymphoma, have been recently recognized. ${ }^{9,10}$ Ken $\mathrm{H}$ Young is a hematopathologist at The University of Texas MD Anderson Cancer Center, Houston, TX, USA. His studies showed that EBV-positive DLBCL exhibited rare genetic alterations. However, similar to other EBV-positive LPDs, EBV-positive DLBCL more frequently expressed NF- $\mathrm{B}$ p50, phosphorylated STAT-3 and CD30 compared with EBV-negative DLBCL. ${ }^{11-13}$ Here, Ken H Young and his colleague review the current understanding of EBV-induced lymphomagenesis, with a focus on the biology, diagnosis and management of EBV-associated B-cell LPD.

EBV-positive T-cell and natural killer (NK)-cell LPDs comprize several disease entities with a broad clinicopathological spectrum. Aggressive NK-cell leukemia and extranodal NK-/T-cell lymphoma are recognized as the prototypes of EBV-positive T- or NK-cell leukemia/lymphoma, respectively. Chronic active EBV infection (CAEBV), hydroa-like T-/NKcell LPD, and severe mosquito bite allergy are peculiar forms of EBV-associated systemic or cutaneous T-/NK-cell LPDs. These diseases have various clinical findings that range from indolent to aggressive and varying degrees of cellular transformation, which depend on the host's immunity, as well as viral factors. ${ }^{14,15}$ The development of EBV-positive T- and NK-cell LPDs is closely associated with ethnicity and occurs more frequently in Asia and Latin America than in North America and Europe. ${ }^{16,17}$ Qingqing Cai is a medical oncologist at Sun 
Yat-sen University Cancer Center, Guangzhou, China. Here, he and his colleagues review the current knowledge about the genetics, oncogenesis, biology, diagnosis and treatment of EBV-associated T-/NK-cell LPDs.

Nasopharyngeal carcinoma and gastric adenocarcinoma are representative epithelial malignancies associated with EBV. Approximately $9 \%$ of gastric carcinomas have EBV in the tumor cells. ${ }^{18}$ A unique feature of EBV-positive gastric carcinoma is extreme $\mathrm{CpG}$ island hypermethylation, including both promoter and nonpromoter $\mathrm{CpG}$ islands of the human genome. $^{19,20}$ Margaret L Gulley is a pathologist at the University of North Carolina whose work includes molecular assays of EBV in human samples, EBV carcinogenesis and EBV-positive gastric carcinoma. ${ }^{21-24} \mathrm{Her}$ article describes the characteristics of EBV-positive gastric carcinoma, the current state of the development of genomic assays to detect gastric cancer, and the opportunities to capitalize on EBV and its effectors as targets for therapy.

EBV infects only humans in nature and a limited number of animal species under experimental conditions. Humanized mice can serve as infection models for human-specific viruses that target cells of the immune system, such as EBV. NOD/Shiscid/IL-2R $\gamma^{\text {null }}$ (NOG) is a highly immunodeficient mouse strain that, after transplantation with cord blood hematopoietic stem cells (HSCs), is able to reconstitute most major components of the hematolymphoid system, including T cells, B cells, NK cells, macrophages and dendritic cells. ${ }^{25}$ These properties make the NOG mouse an excellent model of human virus infections that target the immune system. Shigeyoshi Fujiwara, a pediatrician and virologist at the National Research Institute for Child Health and Development, Japan, has used the NOG mouse to develop models of asymptomatic persistent EBV infection, EBV-positive B-cell LPD and erosive arthritis resembling rheumatoid arthritis and has investigated the EBV-specific immune response. ${ }^{26-28}$ Mouse xenografts using the NOG mouse develop CAEBV and hemophagocytic syndrome, ${ }^{29}$ which occur more frequently in children in Asia and Latin America than in other regions. Fujiwara's review discusses recent findings on the recapitulation of human EBV infection and pathogenesis in these mouse models, as well as the application of this knowledge to preclinical studies of experimental anti-EBV therapies.

The final article discusses the therapeutic approach to EBVassociated LPDs. The clinical impact of EBV infection in cancer cells differs according to the tumor type. In Hodgkin's lymphoma and EBV-positive DLBCL, the prognosis is poor in elderly patients but not in younger patients. ${ }^{30,31} \mathrm{EBV}$ positive $\mathrm{T}$ - and NK-cell leukemia is an aggressive disease that is resistant to the usual chemotherapy, ${ }^{32}$ but the development of L-asparaginase-containing regimens, together with allogeneic HSC transplantation, has led to reasonable improvements in survival. ${ }^{33}$ Yok-Lam Kwong, a hematologist and medical oncologist at Queen Mary Hospital, Hong Kong, reviews the conventional approach to EBV-positive LPDs and the treatment strategies to target EBV.
Accumulating scientific data have led to substantial improvement in our understanding of the oncogenic mechanisms responsible for EBV-associated cancer. Future directions for EBV research include identifying the mechanisms responsible for the cellular immune control of EBV infection, the genetic and epigenetic control of the cell pathways involved in viral persistence and cellular transformation, and the discovery of new therapeutic targets. New technologies, such as deep sequencing with systems biological analysis, are expected to hasten EBV research and biomarker detection.

\section{CONFLICT OF INTEREST}

The author declares no conflict of interest.

Young-Hyeh Ko

Samsung Medical Center, Department of Pathology, Sungkyunkwan University School of Medicine, Seoul, Korea E-mail: yhko310@skku.edu

1 Kushekhar K, van den Berg A, Nolte I, Hepkema B, Visser L, Diepstra A. Genetic associations in classical Hodgkin lymphoma: a systematic review and insights into susceptibility mechanisms. Cancer Epidemiol Biomarkers Prev 2014; 23: 1-11.

2 Tempera I, Lieberman PM. Epigenetic regulation of EBV persistence and oncogenesis. Semin Cancer Biol 2014; 26: 22-29.

3 Cancer Genome Atlas Research Network. Comprehensive molecular characterization of gastric adenocarcinoma. Nature 2014; 513: 202-209.

4 Schmitz R, Ceribelli M, Pittaluga S, Wright G, Staudt LM. Oncogenic mechanisms in Burkitt lymphoma. Cold Spring Harb Perspect Med 2014; 4: pii: a014282.

5 Bellan C, Amato T, Piccaluga PP, Abate F, De Falco G, Ambrosio MR et al. The pressure of the antigens in the pathogenesis of $B L$. Evidence from NGS analysis of BCR. 17th Meeting of the European Association for Haematopathology; 22-27 October 2014; Istanbul. Abstract (OP-LYMP-15), p 61

6 Epstein MA, Achong BG, Barr YM. Virus particles in cultured lymphoblasts from Burkitt's lymphoma. Lancet 1964; 1(7335): 702-703.

7 Hong GK, Gulley ML, Feng WH, Delecluse HJ, Holley-Guthrie E, Kenney SC. Epstein-Barr virus lytic infection contributes to lymphoproliferative disease in a SCID mouse model. J Virol 2005; 79: 13993-14003.

8 Song YJ, Kang MS. Roles of TRAF2 and TRAF3 in Epstein-Barr virus latent membrane protein 1-induced alternative NF-kappaB activation. Virus Genes 2010; 41: 174-180.

9 Asano N, Yamamoto K, Tamaru J, Oyama T, Ishida F, Ohshima K et al. Agerelated Epstein-Barr virus (EBV)-associated B-cell lymphoproliferative disorders: comparison with EBV-positive classic Hodgkin lymphoma in elderly patients. Blood 2009; 113: 2629-2636.

10 Dojcinov SD, Venkataraman G, Pittaluga S, Wlodarska I, Schrager JA Raffeld $\mathrm{M}$ et al. Age-related EBV-associated lymphoproliferative disorders in the Western population: a spectrum of reactive lymphoid hyperplasia and lymphoma. Blood 2011; 117: 4726-4735.

11 Montes-Moreno S, Odqvist L, Diaz-Perez JA, Lopez AB, de Villambrosía SG, Mazorra F et al. EBV-positive diffuse large B-cell lymphoma of the elderly is an aggressive post-germinal center B-cell neoplasm characterized by prominent nuclear factor-kB activation. Mod Pathol 2012; 25: 968-982.

12 Ok CY, Papathomas TG, Medeiros LJ, Young KH. EBV-positive diffuse large B-cell lymphoma of the elderly. Blood 2013; 122: 328-340.

13 Ok CY, Li L, Xu-Monette ZY, Visco C, Tzankov A, Manyam GC et al. Prevalence and clinical implications of Epstein-barr virus infection in de novo diffuse large B-cell lymphoma in Western countries. Clin Cancer Res 2014; 20: 2338-2349.

14 Cohen JI, Kimura H, Nakamura S, Ko YH, Jaffe ES. Epstein-Barr virus associated lymphoproliferative disease in non-immunocompromised hosts: a status report and summary of an international meeting, 8-9 September 2008. Ann Oncol 2009; 20: 1472-1482. 
15 Park S, Ko YH. Epstein-Barr virus-associated T/natural killer-cell lymphoproliferative disorders. J Dermatol 2014; 41: 29-39.

16 Laurini JA, Perry AM, Boilesen E, Diebold J, Maclennan KA, Müller-Hermelink HK et al. Classification of non-Hodgkin lymphoma in Central and South America: a review of 1028 cases. Blood 2012; 120: 4795-4801.

17 Park S, Ko YH. Peripheral T cell lymphoma in Asia. Int J Hematol 2014; 99: 227-239.

18 Murphy G, Pfeiffer R, Camargo MC, Rabkin CS. Meta-analysis shows that prevalence of Epstein-Barr virus-positive gastric cancer differs based on sex and anatomic location. Gastroenterology 2009; 137: 824-833.

$19 \mathrm{Kim}$ J, Lee HS, Bae SI, Lee YM, Kim WH. Silencing and CpG island methylation of GSTP1 is rare in ordinary gastric carcinomas but common in Epstein-Barr virus-associated gastric carcinomas. Anticancer Res 2005; 25: 4013-4019.

20 Qu Y, Dang S, Hou P. Gene methylation in gastric cancer. Clin Chim Acta 2013; 424: 53-65.

21 Gulley ML, Fan H, Elmore SH. Validation of Roche LightCycler Epstein-Barr virus quantification reagents in a clinical laboratory setting. J Mol Diagn 2006; 8: 589-597.

22 Ryan JL, Jones RJ, Kenney SC, Rivenbark AG, Tang W, Knight ER et al. Epstein-Barr virus-specific methylation of human genes in gastric cancer cells. Infect Agent Cancer 2010; 5: 27.

23 Ryan JL, Shen YJ, Morgan DR, Thorne LB, Kenney SC, Dominguez RL et al. Epstein-Barr virus infection is common in inflamed gastrointestinal mucosa. Dig Dis Sci 2012; 57: 1887-1898.

24 Tang W, Morgan DR, Meyers MO, Dominguez RL, Martinez E, Kakudo K et al. Epstein-barr virus infected gastric adenocarcinoma expresses latent and lytic viral transcripts and has a distinct human gene expression profile. Infect Agent Cancer 2012; 7: 21.

25 Ito M, Hiramatsu H, Kobayashi K, Suzue K, Kawahata M, Hioki K et al. NOD/SCID/gamma(c)(null) mouse: an excellent recipient mouse model for engraftment of human cells. Blood 2002; 100: 3175-3182.

26 Yajima M, Imadome K, Nakagawa A, Watanabe S, Terashima K, Nakamura $\mathrm{H}$ et al. A new humanized mouse model of Epstein-Barr virus infection that reproduces persistent infection, Iymphoproliferative disorder, and cell-mediated and humoral immune responses. J Infect Dis 2008; 198: 673-682.

27 Kuwana Y, Takei M, Yajima M, Imadome K, Inomata H, Shiozaki M et al. Epstein-Barr virus induces erosive arthritis in humanized mice. PLOS ONE 2011; 6: e26630.

28 Fujiwara S. Reproduction of Epstein-barr virus infection and pathogenesis in humanized mice. Immune Netw 2014; 14: 1-6.

29 Imadome K, Yajima M, Arai A, Nakazawa A, Kawano F, Ichikawa S et al. Novel mouse xenograft models reveal a critical role of CD4+ T cells in the proliferation of EBV-infected T and NK cells. PLoS Pathog 2011; 7: e1002326.

30 Kwon JM, Park YH, Kang JH, Kim K, Ko YH, Ryoo BY et al. The effect of Epstein-Barr virus status on clinical outcome in Hodgkin's lymphoma. Ann Hematol 2006; 85: 463-468.

31 Park S, Lee J, Ko YH, Han A, Jun HJ, Lee SC et al. The impact of EpsteinBarr virus status on clinical outcome in diffuse large B-cell lymphoma. Blood 2007; 110: 972-978.

32 Tse E, Kwong YL. Treatment algorithms for mature T-cell and natural killercell neoplasms. Future Oncol 2011; 7: 1101-1112.

33 Yamaguchi M, Kwong YL, Kim WS, Maeda Y, Hashimoto C, Suh C et al. Phase II study of SMILE chemotherapy for newly diagnosed stage IV, relapsed, or refractory extranodal natural killer (NK)/T-cell lymphoma, nasal type: the NK-Cell Tumor Study Group study. J Clin Oncol 2011; 29: 4410-4416.

(c) (1) () () This work is licensed under a Creative Commons Attribution-NonCommercial-NoDerivs 3.0 Unported License. The images or other third party material in this article are included in the article's Creative Commons license, unless indicated otherwise in the credit line; if the material is not included under the Creative Commons license, users will need to obtain permission from the license holder to reproduce the material. To view a copy of this license, visit http://creativecommons.org/licenses/by-nc-nd/3.0/ 